\title{
Characterisation of 11 $\beta$-hydroxysteroid dehydrogenase 1 in human orbital adipose tissue: a comparison with subcutaneous and omental fat
}

\author{
Iwona J Bujalska ${ }^{1}$, Omar M Durrani ${ }^{2}$, Joseph Abbott ${ }^{2}$, Claire U Onyimba ${ }^{1,2}$, Pamela Khosla ${ }^{1,2}$, \\ Areeb H Moosavi ${ }^{3}$, Tristan T Q Reuser ${ }^{3}$, Paul M Stewart ${ }^{1}$, Jeremy W Tomlinson ${ }^{1}$, Elizabeth A Walker ${ }^{1, *}$ \\ and Saaeha Rauz ${ }^{2, *}$ \\ ${ }^{1}$ Department of Endocrinology, Division of Medical Sciences, ${ }^{2}$ Academic Unit of Ophthalmology, Division of Immunity and Infection, University of \\ Birmingham, ${ }^{3}$ Birmingham and Midland Eye Centre, Dudley Road, Birmingham B18 7QU, UK \\ (Requests for offprints should be addressed to S Rauz Academic; Email: s.rauz@bham.ac.uk) \\ *(E A Walker and S Rauz share the role of senior author)
}

\begin{abstract}
Glucocorticoids (GCs) have a profound effect on adipose biology increasing tissue mass causing central obesity. The prereceptor regulation of GCs by $11 \beta$-hydroxysteroid dehydrogenase type 1 (11ß-HSD1) that activates cortisol from cortisone has been postulated as a fundamental mechanism underlying the metabolic syndrome mediating adipocyte hyperplasia and hypertrophy in the omental $(\mathrm{OM})$ depot. Orbital adipose tissue $(\mathrm{OF})$ is the site of intense inflammation and tissue remodelling in several orbital inflammatory disease states. In this study, we describe features of the GC metabolic pathways in normal human OF depot and compare it with subcutaneous (SC) and OM depots. Using an automated histological characterisation technique, OF adipocytes were found to be significantly smaller (parameters: area, maximum diameter and perimeter) than $\mathrm{OM}$ and SC adipocytes $(P<0 \cdot 001)$. Although immunohistochemical analyses demonstrated resident $\mathrm{CD}^{+} 8^{+}$cells in all three
\end{abstract}

whole tissue adipose depots, OF CD68 mRNA and protein expression exceeded that of $\mathrm{OM}$ and SC (mRNA, $P<0 \cdot 05$; protein, $P<0 \cdot 001)$. In addition, there was higher expression of glucocorticoid receptor (GR) $\alpha$ mRNA in the OF whole tissue depot $(P<0 \cdot 05)$. Conversely, 11 $\beta$-HSD1 mRNA together with the markers of late adipocyte differentiation (FABP4 and G3PDH) were significantly lower in OF. Primary cultures of $\mathrm{OF}$ preadipocytes demonstrated predominant $11 \beta$-HSD1 oxoreductase activity with minimal dehydrogenase activity. Orbital adipocytes are smaller, less differentiated, and express low levels of $11 \beta$-HSD 1 but abundant GR $\alpha$ compared with SC and OM. OF harbours a large $\mathrm{CD} 8^{+}$population. These characteristics define an orbital microenvironment that has the potential to respond to sight-threatening orbital inflammatory disease.

Journal of Endocrinology (2007) 192, 279-288

\section{Introduction}

Adipose tissue is a highly active endocrine organ regulated not only by a range of external factors, such as the autonomic nervous system and circulating hormones, but also has the ability to modulate its own metabolic activity. One important group of regulating factors are the adrenocorticosteroids. Of these, glucocorticoids (GCs) have a profound effect on adipose biology increasing tissue mass giving rise to obesity in conditions such as Cushing's disease or following the use of exogenous glucocorticoids. Their role in simple obesity is, however, controversial. Regulation of adipose tissue mass involves integration of a variety of complex mechanisms, including the enzyme $11 \beta$-hydroxysteroid dehydrogenase

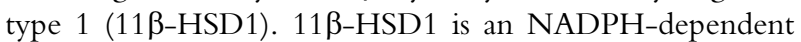
short-chain alcohol dehydrogenase, localised in the lumen of the endoplasmic reticulum, that interconverts active and inactive GCs (Tomlinson et al. 2004). Although it has bidirectional capacity, in vivo it functions as an oxo-reductase activating cortisol from cortisone due to the provision of a cofactor, NADPH, by a second regulatory enzyme, hexose6-phosphate dehydrogenase (H6PDH), thereby mediating glucocorticoid receptor (GR) responses (Draper et al. 2003, Bujalska et al. 2005). 11ß-HSD1 is involved in a number of disease processes, including insulin resistance (Kotelevtsev et al. 1997), osteoporosis (Cooper et al. 2000, Tomlinson et al. 2000), glaucoma (Rauz et al. 2003), ocular surface renewal (Onyimba et al. 2006), inflammation (Thieringer et al. 2001, Zhang et al. 2005) and the metabolic syndrome - a cluster of cardiovascular risk factors, including hypertension, obesity, hyperlipidaemia and insulin resistance (Masuzaki et al. 2003).

$11 \beta$-HSD1 is highly expressed in human omental (OM) and subcutaneous (SC) tissue, although expression and activity are higher in OM preadipocytes, the fibroblast-like 
precursors of mature adipocytes, when compared with SC adipose tissue (Bujalska et al. 1997, 1999). The enzyme is induced upon adipocyte differentiation in human adipose tissue cultures (preadipocytes to adipocytes) and is thought to be related to a 'switch' in enzyme set point from dehydrogenase (preadipocytes) to oxo-reductase (adipocytes) without any significant change in $11 \beta$-HSD 1 mRNA levels (Bujalska et al. 2002). This observation is explained by the induction of H6PDH across differentiation (Bujalska et al. 2005). With the known effect of glucocorticoids on adipose tissue function and distribution, it has been postulated that the enhanced conversion of cortisone to cortisol within omental adipose tissue plays an important role in the pathogenesis of central obesity (Bujalska et al. 2002, Tomlinson et al. 2002).

Cortisol generation after exogenous introduction of cortisone, however, is reduced with increasing body mass index (BMI), and a reduction in activity and expression of 11ß-HSD1 in OM preadipocytes derived from samples taken from obese volunteers, is seen. These data suggest that hepatic $11 \beta$-HSD1 protects against the metabolic effects of simple obesity (Tomlinson et al. 2004). Nevertheless, central obesity is a characteristic feature of mice overexpressing $11 \beta$-HSD1 within adipocytes (Masuzaki et al. 2001). The mechanisms underlying obesity are complex, but recent findings suggest a further role for chronic inflammation that may activate adipose tissue. Increased accumulation of $\mathrm{CD}^{+} 8^{+}$macrophages is seen in SC adipose depots in patients with high BMI and obese phenotypes, and increased expression of monocyte chemoattractant protein (MCP)-1, macrophage inflammatory protein (MIP)-1 $\alpha$ and MAC-1 is evident in rodent white adipose tissue after diet-induced obesity (Weisberg et al. 2003, Wellen \& Hotamisligil 2003, Xu et al. 2003).

Orbital fat (OF) represents a highly specialised adipose tissue depot that occupies the space behind the eyeball (known as the orbit). OF fills most of the orbital cavity, and surrounds the globe, extraocular muscles, nerves and vessels providing support to these delicate structures and protecting against sight-threatening mechanical and inflammatory trauma (Wolfram-Gabel \& Kahn 2002). Two types of orbital adipose tissue have been defined: anterior OF consisting chiefly of small adipocytes that are separated by thick conjunctival septa providing support to intraorbital structures, and posterior OF consisting of larger adipocytes separated by thin conjunctival septa enabling structural movements within the orbit (Bremond-Gignac et al. 2004). Over 60\% of orbital disorders are inflammatory in origin (Rootman 2002). OF is the site for intense inflammation in several disease states of the orbit including local conditions, such as orbital cellulitis, orbital myositis, idiopathic orbital inflammatory disease, as well as systemic metabolic disorders (thyroid-associated ophthalmopathy) and generalised vasculitides (Wegener's granulomatosis). Orbital fibroblasts and other resident orbital cells (macrophages and dendritic cells) are known to participate in the initiation and perpetuation of many of these disease processes secreting mediators that are crucial to orchestrating orbital immune and inflammatory responses and tissue matrix remodelling (Burnstine et al. 1998, Heufelder 2000). OF, like SC and OM depots, expresses GR (Heufelder et al. 1992, Burnstine et al. 1998, Muhlberg et al. 2000). Exogenous GCs are known to modulate the autocrine and paracrine interactions between $\mathrm{OF}$ and resident or infiltrating inflammatory cells (lymphocytes and macrophages), leading to the secretion of chemokines and cytokines (Burnstine et al. 1998, Valyasevi et al. 2001, Kumar \& Bahn 2003, Chen et al. 2005), mediating OF proliferation (Heufelder \& Bahn 1994) and production of matrix proteins (Kaback \& Smith 1999, Han \& Smith 2005). To date, no studies have characterised the role of $11 \beta-H S D 1$ and the pre-receptor regulation of endogenous glucocorticoids in OF. In this study, we describe features of the GC metabolic pathways in normal human $\mathrm{OF}$ depot and compare it with SC and OM depots.

\section{Materials and Methods}

\section{Collection of human adipose tissue}

Paired OM and SC fat was obtained from 50 non-obese (BMI < $25 \mathrm{~kg} / \mathrm{m}^{2}$ ) patients undergoing elective abdominal surgery for non-malignant conditions. Surgically acquired normal orbital adipose tissue specimens (avoiding the anterior and nasal orbital adipose tissue) were obtained from 40 non-obese $(\mathrm{BMI}<$ $25 \mathrm{~kg} / \mathrm{m}^{2}$ ) patients undergoing orbital or eyelid reconstructive procedures carried out at a regional tertiary referral centre (Birmingham and Midland Eye Centre, Birmingham, UK). Patients with orbital tumours, those on exogenous corticosteroids, or with underlying endocrine disease were excluded from the study. Each fat specimen was fixed in formalin, stored in RNAlater at $-20{ }^{\circ} \mathrm{C}$ for RNA extraction or placed in a sterile universal container for immediate processing where sufficient starting tissue was available.

\section{Characterisation of whole tissue adipocyte morphology}

Formalin fixed paraffin embedded $5 \mu \mathrm{m}$ sections of $\mathrm{OF}$ $(n=17)$, SC $(n=8)$ and OM tissue $(n=8)$ were stained with haematoxylin and eosin and photographed in triplicate using an Olympus-BH-2-RFC microscope (Olympus UK Ltd, Southall, Middx, UK) and MicroFireTM-S99808 camera (Indigo Scientific, Baldock, Herts, UK). The images were processed using the green channel to enhance edge prominence using Image-Pro Plus (v4.0, Media Cybernetics, Silver Spring, MD, USA). Software parameters were optimised in order to identify the visual edge of the cell membrane and generate an outline of the cell profiles for analysis. The scaling factor was calculated by photographing a micro-grid counting area of $500 \times 584 \mu \mathrm{m}$ capturing a minimum of 100 cells (the exact number varying according to the size of the adipocytes). Images were taken in triplicate for each specimen, i.e. approximately 300 adipocytes were evaluated for each histological section examined. The following descriptive variables were measured: cell diameter, 
length of longest line joining two points and passing through centroid; roundness, ((perimeter) $2 / 4 \pi$ area); radius ratio, largest radius/smallest radius; feret length, calliper longest length; cell area $\left(\mu \mathrm{m}^{2}\right)$; heterogeneity, fraction of pixels that deviate more than $10 \%$ from average intensity and margination, relative distribution of object intensity between centre and margin (larger value represents brighter centre and 0.33 represents homogeneity).

\section{Immunohistochemistry}

Immunohistochemical analyses were performed on $5 \mu \mathrm{m}$ sections OF, SC and OM tissues mounted on charged slides.

CD68 immunohistochemistry Dewaxed and rehydrated slides of OF, SC and OM sections were blocked with hydrogen peroxide for $15 \mathrm{~min}$ before antigen retrieval using Tris/EDTA tris-buffered saline (TBS) buffer at $\mathrm{pH} 7 \cdot 8$ and a microwave at full power $(900 \mathrm{~W})$ for $15 \mathrm{~min}$. All sections were allowed to cool to room temperature before being rinsed in water. All incubations and washes were performed using the Shandon sequenza. A biotin block was performed on the sections for $10 \mathrm{~min}$ using the Zymed avidin/biotin blocking kit (Invitrogen Ltd) before incubating with primary antibody (CD68 clone PG-M1 (Dako, Carpinteria, CA, USA) 1:100 dilution) in $10 \%(\mathrm{v} / \mathrm{v})$ normal swine serum in TBS buffer for $60 \mathrm{~min}$. Negative control sections were incubated in TBS buffer without primary antibody. The positive control sections used were human tonsil tissue. The sections were then washed in TBS buffer before incubating in Link reagent (Dakocytomation (yellow)) for $10 \mathrm{~min}$. The sections were then rinsed again in TBS buffer ( $\mathrm{pH} 7 \cdot 8$ ), incubated with streptavidin reagent from Dakocytomation (red) for $10 \mathrm{~min}$, rinsed in TBS buffer $(\mathrm{pH} 7 \cdot 8)$ before incubating with CheMate liquid 3,3'-diaminobenzidine (DAB; TBS buffer, 1:50) for approximately $10 \mathrm{~min}$. Finally, sections were counterstained with Meyer's haematoxylin for $45 \mathrm{~s}$ and processed $100 \%(\mathrm{v} / \mathrm{v})$ ethanol and xylene. CD68 positive cells were counted in triplicate by masked observers in three identical fields of view per slide for each adipose depot.

11 $\beta$-HSD immunohistochemistry Immunoperoxidase studies were performed on OF sections using antisera raised in sheep against human 11 $\beta$-HSD1 (amino acid residues 18-33) and $11 \beta-H S D 2$ (amino acid residues 137-160 and 334-358; The Binding Site, Birmingham, UK). Antibody dilutions were in the ratio of $1: 100$ for $11 \beta-H S D 1$ and $1: 100$ for $11 \beta$ HSD2. Control sections included the omission of primary antibody and use of antibody pre-treated with the immunising peptides. Secondary antibodies comprised donkey antisheep peroxidase conjugate (1:100; Binding Site). Sections were visualised with the peroxidase substrate DAB. Human liver and kidney sections were used as positive control tissues for $11 \beta-H S D 1$ and $11 \beta-H S D 2$ respectively.

\section{Orbital preadipocyte isolation and primary cultures}

Orbital $(n=12)$, SC $(n=34)$ and OM $(n=34)$ preadipocytes were isolated using methodology previously reported (Bujalska et al. 2002). The OF protocol was adapted to maximise yield from the small sample size. Briefly, orbital adipose tissue biopsies were washed in PBS containing $50000 \mathrm{U} / 1$ penicillin and $50000 \mu \mathrm{g} / 1$ streptomycin (Life Technologies, Inc.). The tissue was minced with sterile scissors in a Class II culture hood and digested with collagenase class I $(2 \mathrm{mg} / \mathrm{ml}$; Worthington Biochemical Corp., Reading, UK) in $1 \times$ Hanks' Balanced Salt Solution (Gibco Invitrogen Corporation) for $45 \mathrm{~min}$ at $37^{\circ} \mathrm{C}$. Samples were centrifuged at $500 \mathrm{~g}$ for $1 \mathrm{~min}$, and the supernatant containing connective tissue debris, collagenase and lipid was removed leaving a pellet containing preadipocytes. The cellular pellet was washed with Dulbecco's modified Eagle's medium DMEM/Nutrient Mixture F-12 (Gibco) containing $15 \%(\mathrm{v} / \mathrm{v})$ foetal calf serum (Gibco) and seeded on 48-well plates. Cells were left overnight to attach and all unattached cells (including red blood cells) were washed the following day with $1 \times$ Hanks' Balanced Salt Solution. Enzyme assays were performed in duplicate when preadipocytes were confluent at approximately 10 days of culture (see below). The identity of cells were confirmed by differentiating preadipocytes from one well of the 48-well plate into mature lipid containing adipocytes ( $>90 \%$ cultured cells) using chemically defined media.

\section{$11 \beta$-HSD enzyme assays in cultured orbital preadipocytes}

In confluent OF preadipocytes, the culture medium was replaced with serum-free medium $2 \mathrm{~h}$ before incubation. Dehydrogenase activity (cortisol to cortisone conversion) was assessed using $100 \mathrm{nM}$ unlabelled cortisol (Sigma Chemical Co) diluted in serum-free medium and tracer amounts $(1.5 \mathrm{nM})$ of $\left[{ }^{3} \mathrm{H}\right]$ cortisol (specific activity $74 \cdot 0 \mathrm{Ci} / \mathrm{mmol}$; NEN, Boston, MA, USA) at $37^{\circ} \mathrm{C}$ for $24 \mathrm{~h}$. Conversion of cortisone to cortisol (oxo-reductase) was analysed by incubating cells with $100 \mathrm{nM}$ cortisone and tracer amounts of $\left[{ }^{3} \mathrm{H}\right]$ cortisone $(50000$ c.p.m.) synthesised in-house (Stewart et al. 1994). After 24-h incubation, steroids were extracted from the medium with ten volumes of dichloromethane, separated by thin-layer chromatography with chloroform:ethanol (92:8) as a mobile phase and the fractional conversion of steroids was calculated after scanning analysis using a Bioscan 2000 radioimaging detector (Bioscan, Washington, DC, USA). Following enzyme assay, cell monolayers were lysed in $1 \mathrm{ml}$ water for subsequent protein assays. Total protein in each well was determined using a standard protein assay reagent (Bio-Rad), and enzyme activities were expressed as $\mathrm{pmol} / \mathrm{h}$ per $\mathrm{mg}$. All assays were carried out in duplicate for each preadipocyte primary culture derived from individual patient samples. 
Whole human adipose tissue RNA extraction and reverse transcription

Total RNA was extracted from whole OF $(n=8)$, SC $(n=8)$ and $\mathrm{OM}(n=7)$ tissue stored in RNAlater at $-20{ }^{\circ} \mathrm{C}$ using a single-step extraction method (Tri-Reagent; Sigma-Aldrich). RNA integrity was assessed by electrophoresis on $1 \%(\mathrm{w} / \mathrm{v})$ agarose gels, and quantity was determined spectrophotometrically at $\mathrm{OD}_{260}$. One microgram of total RNA was reverse transcribed in $50 \mu \mathrm{l}$ total volume using TaqMan Reverse Transcription Reagents (Applied Biosystems, Warrington, Cheshire, UK) according to the manufacturer's guidelines. The reaction was terminated by heating the cDNA to $95^{\circ} \mathrm{C}$ for $5 \mathrm{~min}$ and stored at $-20^{\circ} \mathrm{C}$ until required.

\section{Real-time reverse transcriptase-PCR}

11 $\beta$-HSD1, 11 $\beta-H S D 2$, H6PDH, GR $\alpha$, FABP4, G3PDH and CD68 mRNA levels were measured using real-time PCR using an ABI 7500 system (Perkin-Elmer, Biosystems, Warrington, $\mathrm{UK})$. PCR was performed in $25 \mu \mathrm{l}$ reactions on 96-well plates in reaction buffer containing TaqMan universal PCR mastermix (Applied Biosystems), $3 \mathrm{mM} \mathrm{Mn}(\mathrm{Oac}) 2$, $200 \mu \mathrm{M}$ deoxy-NTPs, 1.25 U AmpliTaq Gold polymerase (Perkin-Elmer), 1.25 U AmpErase UNG (Perkin-Elmer), 900 nmol primers, $100-200 \mathrm{nmol}$ TaqMan probe and 25-50 ng cDNA. All reactions were multiplexed with primers specific for $18 \mathrm{~S}$ rRNA (provided as a pre-optimised mix; Perkin-Elmer, Beaconsfield, Bucks, UK) as an internal reference and were carried out in duplicate. Data were obtained as $\mathrm{Ct}$ values (the cycle number at which logarithmic PCR plots cross a calculated threshold line) and used to determine $\mathrm{dCt}$ values $(\mathrm{dCt}=\mathrm{Ct}$ of the target gene minus $\mathrm{Ct}$ of the internal reference, 18S). All target gene probes were labelled with the fluorescent label 6-carboxyfluorescein, and the housekeeping gene was labelled with the fluorescent label VIC. Reactions were as follows: $50^{\circ} \mathrm{C}$ for $2 \mathrm{~min}, 95^{\circ} \mathrm{C}$ for $10 \mathrm{~min}$, and then 40 cycles of $95^{\circ} \mathrm{C}$ for $15 \mathrm{~s}$ and $60^{\circ} \mathrm{C}$ for $1 \mathrm{~min}$. All expression data are presented as fold-change when compared with OF using the equation $2^{-\Delta \Delta \mathrm{Ct}}(\Delta \Delta \mathrm{Ct}$ is the difference between $\mathrm{dCt}$ values in $\mathrm{SC}$ or $\mathrm{OM}$ minus $\mathrm{dCt}$ in $\mathrm{OF}$ ). Sequences of oligonucleotide primers and probes were as follows: (i) $11 \beta-H S D 1$ antisense primer $5^{\prime}$-AGGAAAGCTCATGGGAGGACTAG-3', sense primer $5^{\prime}$-ATGGTGAATATCATCATGAAAAAGATTC- $3^{\prime}$, probe $5^{\prime}$-CATGCTCATTCTCAACCACATCACCAACA-3'; (ii) GR $\alpha$ antisense primer $5^{\prime}$-GCGATGGTCTCAGAAACCAAAC- $3^{\prime}$, sense primer 5'-GAGATTACAGAGGAAGTTATCCTCTGC-3', probe 5'-TGCAGTGAAGGTTGCTGAGGCTCTGA-3'; (iii) H6PDH antisense primer 5'-CAGGTGTCCTAGTGCACATTGAC- $3^{\prime}$, sense primer $5^{\prime}$-GTAGCCCACTCTCTCGTCCAA-3' ${ }^{\prime}$, probe $5^{\prime}$-AAGGCACGCCCTCCCAGCG-3'; (iv) G3PDH antisense primer $5^{\prime}$-CCATCAGTTCATCGGCAAGAT- $3^{\prime}$, sense primer $5^{\prime}$-TCGTCTACCCCCTTAATAAGAGATATG- $3^{\prime}$, probe $5^{\prime}$-AGGGCCATCTGAAGGC
AAACGCC- $3^{\prime}$. Primers and probes for CD68 and FABP4 were from Expression Assays Applied Biosystems.

\section{Ethics and statistical methods}

The collection of human tissues for in vitro investigation was approved by the local ethics committee. Informed consent was obtained from all patient volunteers.

Statistical analysis was performed using the software package SPSS for Windows Version 11.5.1 (SPSS, Inc., Chicago, IL, USA, 2002), Minitab Release 14.12 (Minitab Ltd, Coventry, UK) and Prism for Windows Version $4.03 \mathrm{c}$ (GraphPad Software, Inc., San Diego, CA, USA). Histological characterisation comparisons between the three fat depots were made using a nested general linear model regression analysis for replicated measures of data (to minimise loss of data by averaging individual readings), followed by integrated pairwise comparisons. Data are presented as means and $95 \%$ confidence intervals. Enzyme assay data are presented as means with standard errors of the separate experiments. Real-time PCR analyses were performed with $\mathrm{dCt}$ values to exclude potential bias due to averaging and transforming data through the equation $2^{-\Delta \Delta \mathrm{Ct}}$ to give a fold-change in gene expression. Statistical analyses were performed using a non-parametric Mann-Whitney test for non-normal data, or $t$-test/ANOVA for normally distributed data. $P$ values $<0.05$ were accepted as statistically significant.

\section{Results}

\section{Characterisation of whole tissue adipocyte morphology}

Adipocyte diameter, perimeter and area (Fig. 1A-C respectively) were identified as optimal parameters differentiating adipocyte morphology from the different depots. Mean cell diameter, perimeter, adipocyte area and feret length defined similar trends $(\mathrm{OF}<\mathrm{OM}<\mathrm{SC} ; P<0 \cdot 001)$ across the three adipocyte depots. OF adipocytes were the smallest adipocyte with mean cell diameter $(50 \cdot 7 \mu \mathrm{m}, 95 \% \mathrm{CI} 49 \cdot 8-51 \cdot 6)$, shortest perimeter $(149 \mu \mathrm{m}, 95 \% \mathrm{CI} 146 \cdot 7-152 \cdot 7)$ and smallest area $\left(2470 \mu^{2}, 95 \%\right.$ CI $\left.2382-2560\right)$. SC adipocytes were the largest according to each of these parameters. Radius ratio, cell roundness and margination followed similar trends to each other across the groups but these trends were not significant (OF $>\mathrm{OM}<\mathrm{SC} ; P=\mathrm{NS}$, data not shown), and cell count per area of interest did not differentiate significantly between depots. Representative haematoxylin and eosin-stained photomicrographs detailing histomorphometric characterisation of the three adipose depots are shown in Fig. 1D-F.

\section{Evaluation of $C D 68^{+}$protein and $m R N A$ expression in human adipose depots}

The largest resident $\mathrm{CD} 68^{+}$population was found in the $\mathrm{OF}$ depot (median $7 \cdot 6$ (range 3.8-19.6) cell counts/unit area) 

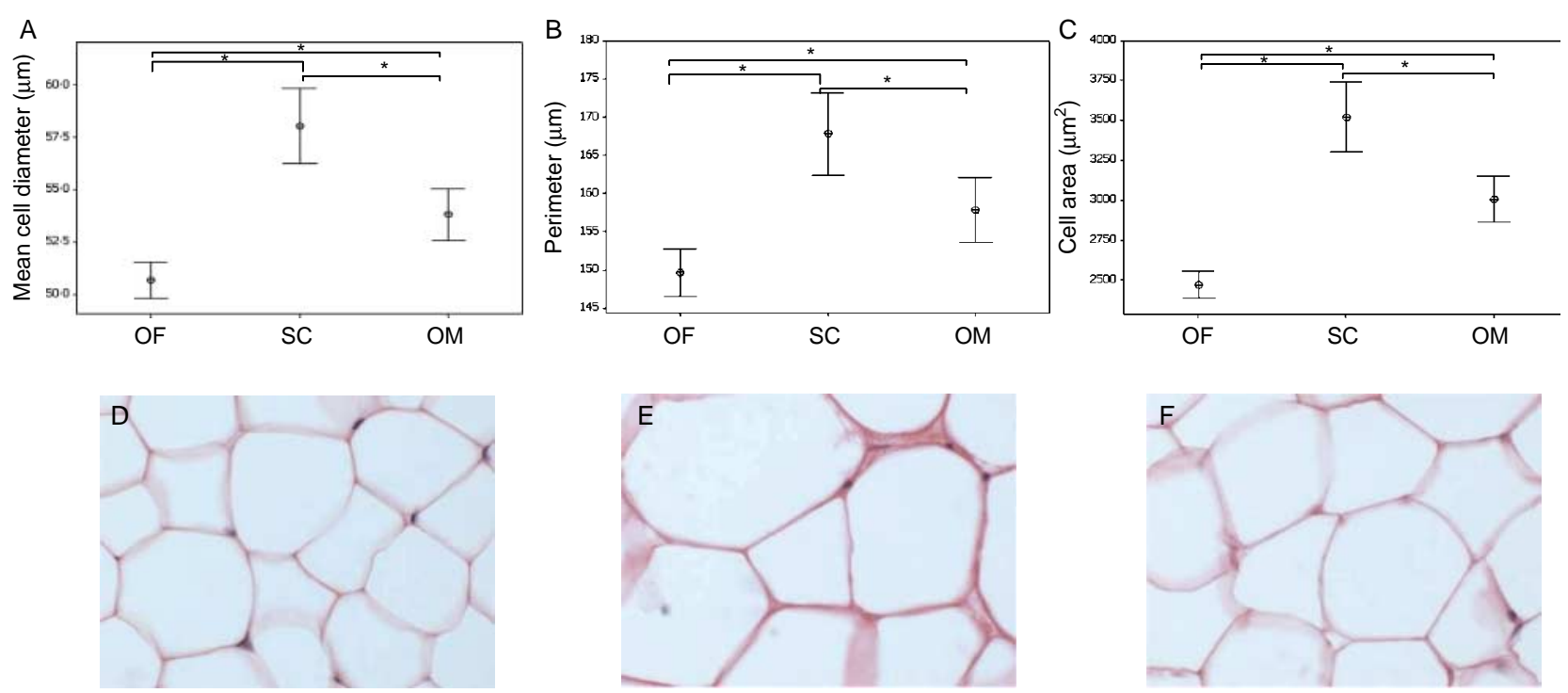

Figure 1 Adipocyte morphology. Diameter of the individual adipocyte (A), perimeter cell diameter (B) and area (C), were identified as optimal characteristics defining adipocyte morphology. Smallest adipocytes were found in the orbital fat (OF) depot (D), while SC adipocytes were the largest cell (E). Omental (OM) adipocytes were statistically larger than OF but smaller than SC (F) (OF, $n=17 ; \mathrm{SC}, n=8 ; \mathrm{OM}, n=8$; results are expressed as mean and $95 \%$ confidence intervals; ${ }^{*} P<0 \cdot 001$ ).

when compared with SC (median $0 \cdot 7$ (range $0 \cdot 1-6 \cdot 5)$ cell counts/unit area, $P<0 \cdot 001$ ) and $\mathrm{OM}$ (median $2 \cdot 9$ (range $0 \cdot 6-5 \cdot 2)$ cell counts/unit area, $P<0 \cdot 001$; Fig. 2A). These findings were endorsed by a similar trend in CD68 mRNA expression for each depot (Fig. 2B $(\mathrm{OF}=1 ; \mathrm{SC}=0 \cdot 21$; $P<0 \cdot 05$; OM $0 \cdot 38<0 \cdot 05$ (fold-change when compared with $\mathrm{OF}))$ ). Representative photomicrographs showing CD68 ${ }^{+}$ macrophages in each whole adipose tissue depot (OF, SC and OM) are shown in Fig. 2C-E.

\section{Characterisation of $11 \beta$-HSD1 expression and activity in orbital fat}

Immunoreactivity was seen for $11 \beta-H S D 1$ antibody in OF sections (Fig. 3A) and around the central vein of human liver (positive control; Fig. 3C). Minimal staining was detected with $11 \beta-H S D 1$ pre-adsorbed antibody (data not shown). No staining was seen with $11 \beta$-HSD2 antibody in OF tissue (Fig. 3B), whereas good staining was visualised in human distal collecting duct epithelium in the kidney (positive control, Fig. 3D).

Primary stromal cultures of $\mathrm{OF}$ preadipocytes, confirmed $11 \beta$-HSD 1 oxo-reductase activity $(0.69 \pm 0.5 \mathrm{pmol} / \mathrm{h}$ per $\mathrm{mg}$ (mean \pm s.E.M.)) when incubated for $24 \mathrm{~h}$ with $100 \mathrm{nM}$ cortisone and minimal dehydrogenase activity $(0.11 \pm 0.08 \mathrm{pmol} / \mathrm{h}$ per $\mathrm{mg}$ (mean \pm s.E.M.); $P<0 \cdot 05$; Fig. 4A-C). Oxo-reductase activity was greatest in $\mathrm{OM}$ preadipocytes when compared with SC $(43 \cdot 7 \pm 5 \cdot 2$ vs $17.6 \pm 3.6 \mathrm{pmol} / \mathrm{mg}$ per h (mean \pm s.E.M.) $P<0.001)$ and OF preadipocytes (OF versus SC; $P<0 \cdot 01$; OF versus $\mathrm{OM}$; $P<0 \cdot 001$; Fig. 4D).
Comparison of $11 \beta-H S D 1$ and glucocorticoid-related target gene expression in whole adipose tissue depots

11ß-HSD1 mRNA was expressed within OF tissue, although quantitative real-time PCR analyses across the three whole adipose tissue depots revealed lowest levels of expression in OF when compared with SC and $\mathrm{OM}$ adipose depots $(\mathrm{OF}=1 ; \quad \mathrm{SC}=8 \cdot 1, \quad P<0 \cdot 001 ; \quad \mathrm{OM}=10<0 \cdot 001 \quad$ (foldchange when compared with OF); Fig. 5A). Nevertheless, these data reflect our $11 \beta$-HSD1 oxo-reductase activity data detailed earlier.

Whole tissue analyses indicated the highest expression of GR $\alpha$ mRNA in OF when compared with SC and OM adipose tissue (Fig. 5A). Conversely, H6PDH mRNA (NADPH provider for 11 $\beta$-HSD1 oxo-reductase activity; Fig. 5A) and markers of late adipocyte differentiation (FABP4, G3PDH) were significantly lower in OF (Fig. 5B).

\section{Discussion}

In this paper, we have described a novel reproducible automated method for the histomorphometric analysis of adipose tissue from differing human depots. This has been performed in the context of gene expression profiling and has identified important depot specific differences in adipocyte biology and GC metabolism.

In comparison with OM and SC depots, orbital adipocytes were significantly smaller, expressed lower levels of adipocyte differentiation markers (FABP4 and G3PDH), but revealed a higher $\mathrm{CD} 8^{+}$cellular infiltrate. Examination of the key players of the GC metabolic pathways, confirmed that all 

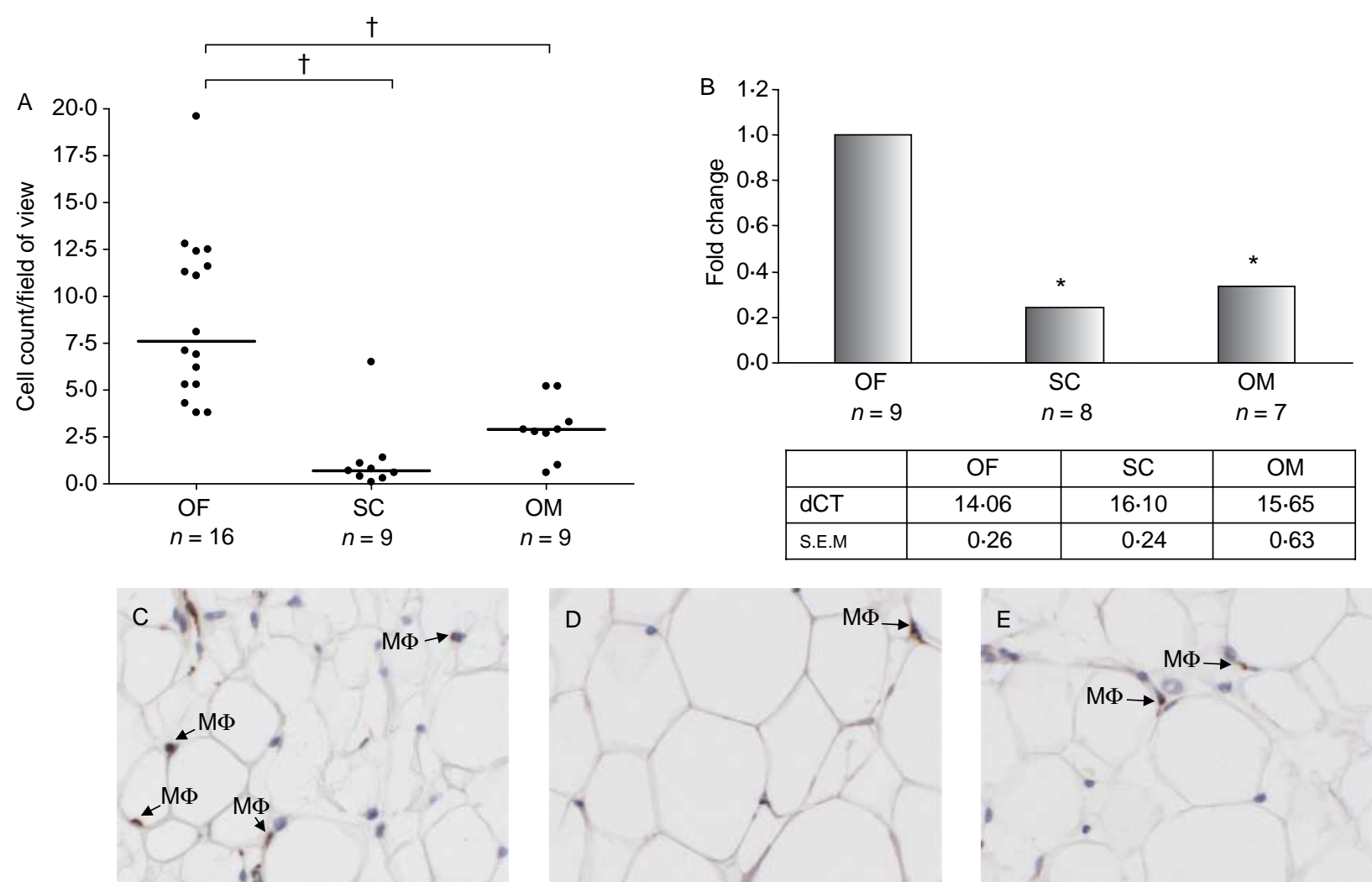

Figure 2 Immunohistochemistry using human anti-CD68 for macrophages confirmed a large resident population in the OF depot when compared with SC and OM (A). Results are expressed as median and full range of counts. These findings were endorsed by real-time RT-PCR CD68 mRNA expression in each of the adipose depots (B). Results are expressed as fold-change when compared with orbital fat; dCt are shown in table below $\left({ }^{*} P<0 \cdot 05 ;{ }^{\dagger} P<0 \cdot 001\right)$. Representative sections of OF, SC and OM adipose depots with identified macrophages (Mø) are shown in $\mathrm{C}, \mathrm{D}$ and $\mathrm{E}$ respectively.

three depots expressed GR $\alpha$ mRNA in keeping with earlier published studies (Heufelder et al. 1992, Burnstine et al. 1998, Muhlberg et al. 2000, Boullu-Ciocca et al. 2003), but expression in the OF depot was significantly higher. In addition, our data has defined 11 $\beta-H S D 1$ oxo-reductase activity and mRNA expression in OF together with its regulatory enzyme, $\mathrm{H} 6 \mathrm{PDH}$, although these were at a lower level than that seen in SC and OM tissues.

These observations highlight the importance of adipose tissue, depot-specific analyses. Adipose tissue is regarded as an 'endocrine organ' and depot specificity of gene expression between SC and OM depots is well described (Montague et al. 1997). Furthermore, these changes are functionally important with differing propensities for adipocyte differentiation, proliferation, apoptosis and lipid metabolism between these depots (Vikman et al. 1995, Niesler et al. 1998). Our data show that orbital adipose tissue is clearly distinct from both SC and OM depots. The fundamental explanation for these differences lies, in addition to genetic and environmental factors, in the embryological origins of adipose connective tissue. Whereas SC and OM 'peripheral' adipose depots and fibroblasts are derived from mesoderm, orbital fibroblasts originate from neuroectoderm (Smith 2004). Studies have shown that orbital and peripheral fibroblasts have both distinguishing morphological phenotypic features (Smith et al. 1995), but also at a molecular level, orbital fibroblasts have distinct defining characteristics, including expression of surface receptors, cellular proteins, responses to cytokines and the ability to secrete and remodel matrix proteins (Prabhakar et al. 2003, Ajjan \& Weetman 2004, Smith 2004). As orbital fibroblasts are neural crest in origin, they possess considerable plasticity - under appropriate in vitro conditions, almost 50\% may be differentiated into lipid containing adipocytes (Smith et al. 2002). Hence, it has been proposed that the unique nature of the orbital molecular environment accounts for its underlying susceptibility to autoimmune diseases (Kaminski et al. 2003).

The impact of the macrophage infiltrate in orbital adipose tissue may also be important particularly as cytokines have potent effects upon adipocyte biology. Recent studies have shown that chronic inflammation activates adipose tissue in simple obesity defined by an increased accumulation of $\mathrm{CD} 8^{+}$macrophages, increased adipocyte size and increased TNFa in patients with high BMIs (Weisberg et al. 2003, 

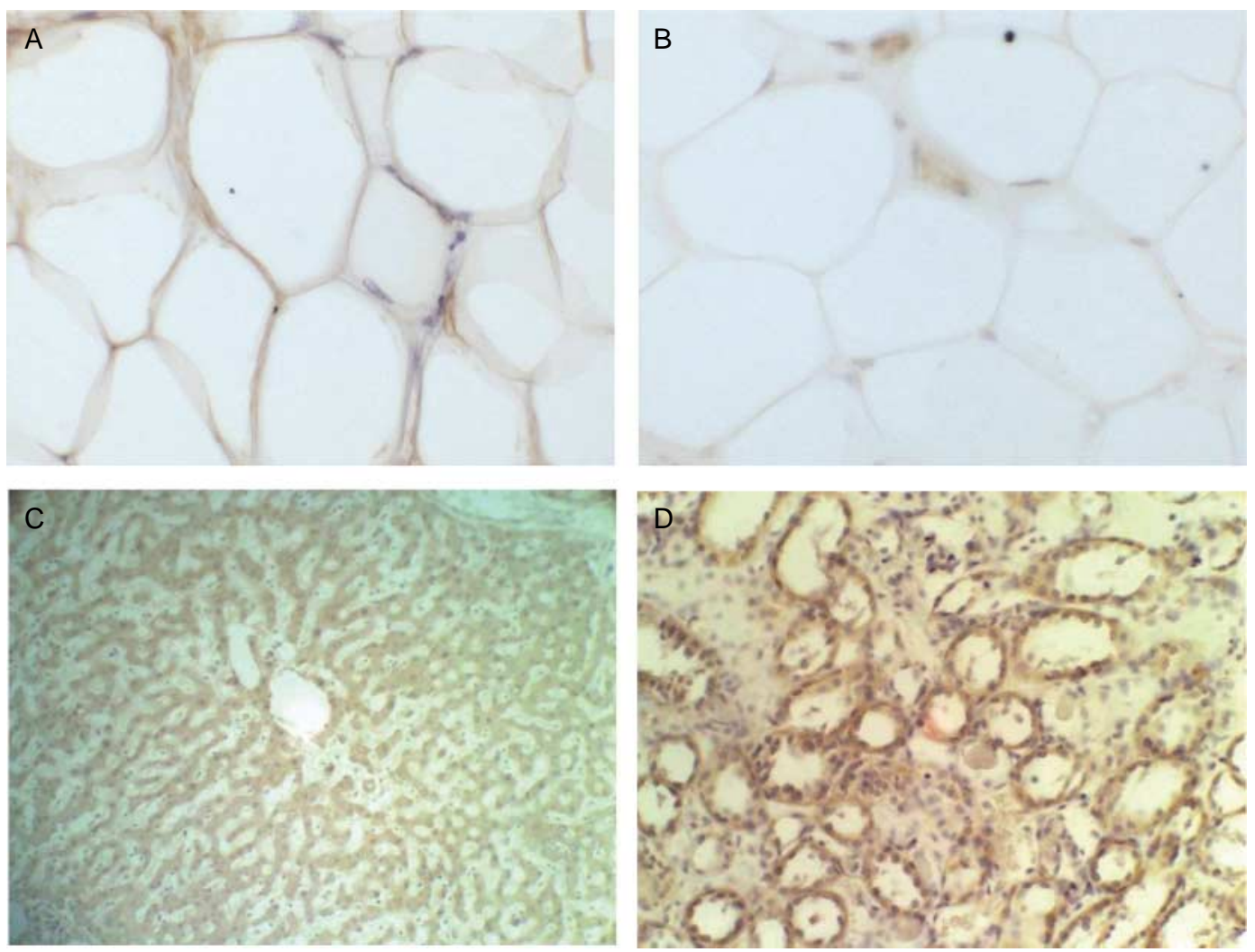

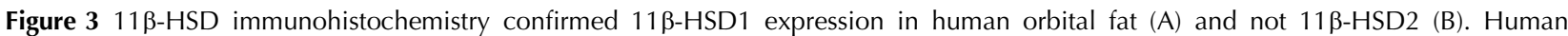

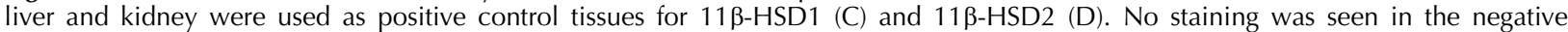
control sections $(n=5)$.

A

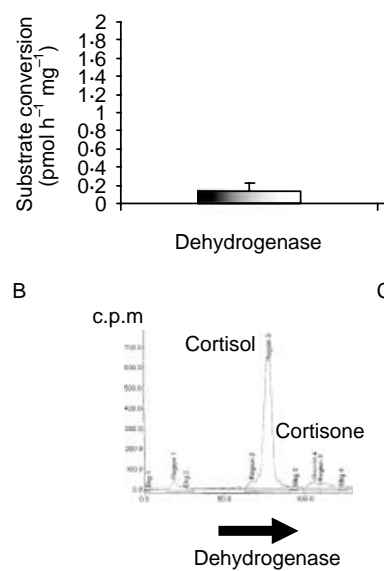

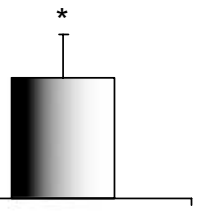

Oxo-reductase

C

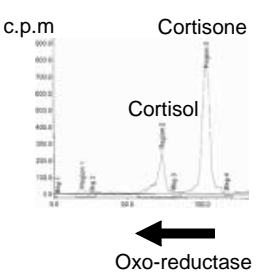

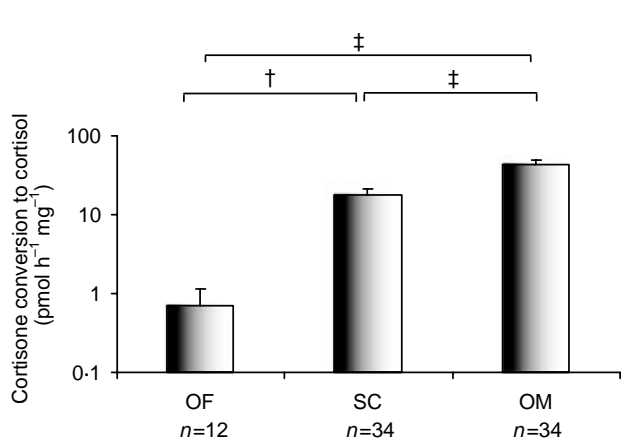

$n=12 \quad n=34 \quad n=34$

Figure 4 Primary cultures of OF preadipocytes confirmed $11 \beta-\mathrm{HSD} 1$ oxo-reductase activity and minimal dehydrogenase activity when incubated for $24 \mathrm{~h}$ with $100 \mathrm{nM}$ cortisone and cortisol respectively $(n=12)$ (A). Representative radiochromatograph traces are shown for dehydrogenase (B) and oxo-reductase (C) activity. (D) Oxo-reductase activity was greatest in OM preadipocytes followed by SC and OF adipocytes $\left({ }^{*} P<0 \cdot 05 ;{ }^{\dagger} P<0 \cdot 01 ;{ }^{\ddagger} P<0 \cdot 001\right)$. 

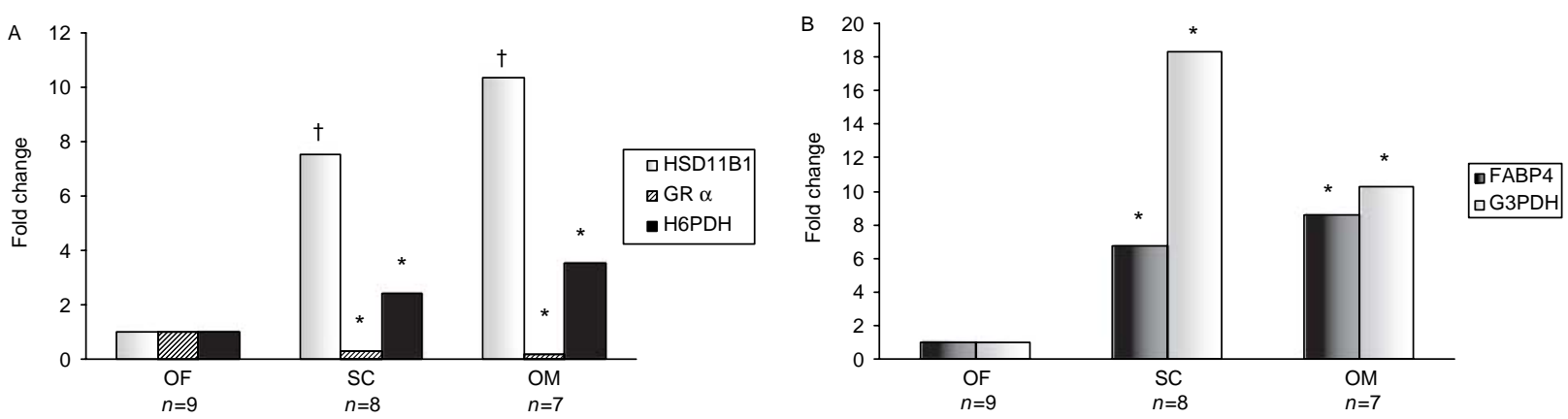

\begin{tabular}{|l|c|c|c|}
\hline$d C t / s . E \cdot M$ & OF & SC & OM \\
\hline HSD11B1 & 17.30 & 14.39 & 13.92 \\
\hline S.E.M & 0.33 & 0.24 & 0.45 \\
\hline GR $\alpha$ & 15.57 & 16.09 & 17.59 \\
\hline S.E.M & 0.61 & 0.54 & 0.91 \\
\hline H6PDH & 16.89 & 14.32 & 15.07 \\
\hline S.E.M & 0.60 & 0.48 & 0.60 \\
\hline
\end{tabular}

\begin{tabular}{|l|c|c|c|}
\hline$d C t /$ S.E.M & OF & SC & OM \\
\hline FABP4 & 11.41 & 7.38 & 8.02 \\
\hline S.E.M & 0.48 & 0.70 & 1.00 \\
\hline G3PDH & 15.13 & 9.64 & 11.57 \\
\hline S.E.M & 0.66 & 0.59 & 0.91 \\
\hline
\end{tabular}

Figure 5 Whole adipose tissue real time RT-PCR analyses showed significantly higher expression of $11 \beta$-HSD1 and H6PDH mRNA in SC and OM when compared with OF. Conversely, highest expression of GR $\alpha$ mRNA in OF when compared with SC and OM is seen (A). FABP4, G3PDH mRNA expression (markers of late adipocyte differentiation) were significantly lower in OF (B). Results are expressed as fold-change when compared with orbital fat; dCt are shown in tables below $\left({ }^{*} P<0 \cdot 05 ;{ }^{\dagger} P<0 \cdot 001\right)$.

Wellen \& Hotamisligil 2003, Neels \& Olefsky 2006, Pietiläinen et al. 2006). There is considerable heterogeneity in monocyte-derived lineages (e.g. macrophages) and the different monocyte subsets reflect the developmental stages with distinct physiological roles, such as recruitment into inflammatory lesions or entry to normal tissues (Gordon \& Taylor 2005). It is thought that with the expansion of adipose tissue during weight gain, induction of a range of signalling pathways activates the adipose vascular fraction allowing monocytes to extravasate through the endothelial cell layer into the adipose tissue where they differentiate into macrophages localising predominantly around dead adipocytes (Neels \& Olefsky 2006). Crosstalk between adipocytes, macrophages and endothelial cells aggravates the inflammatory state, resulting in increased secretion of pro-inflammatory cytokines/chemokines, adipokines and angiogenic factors. Furthermore, the interaction of cytokines and GC metabolism may be an additional contributing factor. TNF $\alpha$, IL- 6 and IL-1 $\beta$ are potent inducers of $11 \beta-H S D 1$ expression and activity in adipose tissue (Tomlinson et al. 2001). Macrophage-derived cytokine production in vivo may serve to augment cortisol generation through induction of $11 \beta-H S D 1$. TNF $\alpha$ specifically, in addition to modulating $11 \beta-H S D 1$ activity, inhibits adipocyte differentiation, proliferation and promotes apoptosis and de-differentiation (Petruschke \& Hauner 1993, Prins et al. 1997). This process may be of considerable relevance to the orbital fat microenvironment. The orbital fat samples analysed in this study were all from healthy controls undergoing elective orbital or lid surgery for non-inflammatory disease states, and despite this, normal OF harboured a large $\mathrm{CD} 68^{+}$population and adipocytes were less differentiated when compared with SC and OM. These data reflect an orbital molecular environment that has an increased potential and plasticity that is vital to combat inflammatory, immune-mediated or infective insult.

The role of GCs in the regulation of adipocyte biology is exemplified by patients with Cushing's syndrome who develop florid, but reversible central obesity. GCs are essential for adipocyte differentiation (Hauner et al. 1987), inhibit omental preadipocyte proliferation (Tomlinson et al. 2002), but interestingly, promote proliferation in the SC depot (Bader et al. 2002). 11ß-HSD1 overexpression in adipose tissues in rodent models induces obesity and the metabolic syndrome (Masuzaki et al. 2001, 2003) and selective $11 \beta$-HSD1 inhibitors have been suggested as a novel therapeutic strategy (Alberts et al. 2002, 2003, Hermanowski-Vosatka et al. 2005). The identification of $11 \beta-H S D 1$ in human orbital adipose tissue is an important finding and raises the possibility that the local generation of GC within this depot may be functionally important. Although levels were lower than those observed in SC and OM depots, the increased expression of GR $\alpha$ is likely to compensate for this. Low levels of oxo-reductase activity have been documented in other tissue depots, notably bone (Cooper et al. 2002). In this tissue, low basal levels are believed to be physiologically significant, as induction of oxo-reduction activity increasing GC bioavailability is seen when osteoblasts are challenged with pro-inflammatory cytokines (Cooper et al. 2001). Critically, unlike the SC and OM depots, the orbital fat depot lies within a confined space surrounding tissues susceptible to compression. Therefore, rapid expansion, 
perhaps as a consequence of enhanced GC autocrine generation through $11 \beta$-HSD1, may have important sightthreatening clinical implications. The possibility of dysregulation of $11 \beta-H S D 1$ in disease states (particularly those with underlying inflammatory and immune-mediated aetiologies) requires further investigation, and a detailed characterisation of expression and functional importance in these conditions is now warranted.

To conclude, orbital adipose tissue is a biologically distinct adipose tissue depot. Adipocytes are smaller and less differentiated than SC and OM. The identification of $11 \beta$ HSD1 and H6PDH expression and activity within the depot, together with an abundant GR $\alpha$ and a large CD68 ${ }^{+}$ population define a microenvironment that has the potential to respond to sight-threatening orbital inflammatory disease. Our data raise the exciting possibility that the autocrine generation of cortisol may be functionally important in regulating orbital adipocyte biology and that this may be amenable to therapeutic modulation.

\section{Acknowledgements}

We would like to thank Charles Shaikh and Susan Hughes for their technical support in the laboratory, and Timothy Marshall for his advice on the statistical analyses. Grant Support: Wellcome Trust Research, UK; SWBH NHS Trust R\&D Major Award 2006. The authors have no proprietary interest in the products described in this article. The authors declare that there is no conflict of interest that would prejudice the impartiality of this scientific work.

\section{References}

Ajjan RA \& Weetman AP 2004 New understanding of the role of cytokines in the pathogenesis of Graves' ophthalmopathy. Journal of Endocrinological Investigation 27 237-245.

Alberts P, Engblom L, Edling N, Forsgren M, Klingström G, Larsson C, Rönquist-Nii Y, Öhman B \& Abrahmsén L 2002 Selective inhibition of $11 \beta$-hydroxysteroid dehydrogenase type 1 decreases blood glucose concentrations in hyperglycaemic mice. Diabetologia 45 1528-1532.

Alberts P, Nilsson C, Selen G, Engblom L, Edling N, Norling S, Klingstrom G, Larsson C, Forsgren M, Ashkzari M et al. 2003 Selective inhibition of $11 \beta$ hydroxysteroid dehydrogenase type 1 improves hepatic insulin sensitivity in hyperglycemic mice strains. Endocrinology 144 4755-4762.

Bader T, Zoumakis E, Friedberg M, Hiroi N, Chrousos G \& Hochberg Z 2002 Human adipose tissue under in vitro inhibition of 11 betahydroxysteroid dehydrogenase type 1: differentiation and metabolism changes. Hormone and Metabolic Research 34 752-757.

Boullu-Ciocca S, Paulmyer-Lacroix O, Fina F, Ouafik LH, Alessi M-C, Oliver C \& Grino M 2003 Expression of the mRNAs coding for the glucocorticoid receptor isoforms in obesity. Obesity Research 11 925-929.

Bremond-Gignac D, Copin H, Cussenot O, Lassau J-P \& Henin D 2004 Anatomical, histological and mesoscopic study of the adipose tissue of the orbit. Surgical and Radiologic Anatomy 26 297-302.

Bujalska IJ, Kumar S \& Stewart PM 1997 Does central obesity reflect 'Cushing's disease of the omentum'? Lancet 349 1210-1213.

Bujalska IJ, Kumar S, Hewison M \& Stewart PM 1999 Differentiation of adipose stromal cells: the roles of glucocorticoids and $11\{$ beta $\}-$ hydroxysteroid dehydrogenase. Endocrinology 140 3188-3196.
Bujalska IJ, Walker EA, Hewison M \& Stewart PM 2002 A switch in dehydrogenase to reductase activity of $11 \beta$-hydroxysteroid dehydrogenase type 1 upon differentiation of human omental adipose stromal cells. Journal of Clinical Endocrinology and Metabolism 87 1205-1210.

Bujalska IJ, Draper N, Michialidou Z, Tomlinson JW, White PC, Chapman KE, Walker EA \& Stewart PM 2005 Hexose-6-phosphate dehydrogenase confers oxo-reductase activity upon $11 \beta$-hydroxysteroid dehydrogenase type 1. Journal of Molecular Endocrinology 35 675-684.

Burnstine MA, Elner SG \& Elner VM 1998 Orbital fibroblast chemokine modulation: effects of dexamethasone and cyclosporin A. British Journal of Ophthalmology 82 318-322.

Chen B, Tsui S \& Smith TJ 2005 IL-1 $\{$ beta\} induces IL-6 expression in human orbital fibroblasts: identification of an anatomic-site specific phenotypic attribute relevant to thyroid-associated ophthalmopathy. Journal of Immunology 175 1310-1319.

Cooper MS, Walker EA, Bland R, Fraser WD, Hewison M \& Stewart PM 2000 Expression and functional consequences of $11 \beta$-hydroxysteroid dehydrogenase activity in human bone. Bone 27 375-381.

Cooper MS, Bujalska I, Rabbitt EA, Walker EA, Bland R, Sheppard MC, Hewison M \& Stewart PM 2001 Modulation of 11 $\beta$-hydroxysteroid dehydrogenase isozymes by proinflammatory cytokines in osteoblasts: an autocrine switch from glucocorticoid inactivation to activation. Journal of Bone and Mineral Research 16 1037-1044.

Cooper MS, Rabbitt EH, Goddard PE, Bartlett WA, Hewison M \& Stewart PM 2002 Osteoblastic $11 \beta$-hydroxysteroid dehydrogenase type 1 activity increases with age and glucocorticoid exposure. Journal of Bone and Mineral Research 17 979-986.

Draper N, Walker EA, Bujalska IJ, Tomlinson JW, Chalder SM, Arlt W, Lavery GG, Bedendo O, Ray DW, Laing I et al. 2003 Mutations in the genes encoding 11beta-hydroxysteroid dehydrogenase type 1 and hexose-6phosphate dehydrogenase interact to cause cortisone reductase deficiency. Nature Genetics 34 434-439.

Gordon S \& Taylor PR 2005 Monocyte and macrophage heterogeneity. Nature Reviews. Immunology 5 953-964.

Han R \& Smith TJ 2005 Induction by IL-1 $\beta$ of tissue inhibitor of metalloproteinase- 1 in human orbital fibroblasts: modulation of gene promoter activity by IL-4 and IFN- $\gamma$. Journal of Immunology 174 3072-3079.

Hauner H, Schmid P \& Pfeiffer EF 1987 Glucocorticoids and insulin promote the differentiation of human adipocyte precursor cells into fat cells. Journal of Clinical Endocrinology and Metabolism 64 832-835.

Hermanowski-Vosatka A, Balkovec JM, Cheng K, Chen HY, Hernandez M, Koo GC, Le Grand CB, Li Z, Metzger JM, Mundt SS et al. 200511 beta\}HSD1 inhibition ameliorates metabolic syndrome and prevents progression of atherosclerosis in mice. Journal of Experimental Medicine 202 517-527.

Heufelder AE 2000 Pathogenesis of ophthalmopathy in autoimmune thyroid eye disease. Reviews in Endocrine and Metabolic Disorders 1 87-95.

Heufelder AE \& Bahn RS 1994 Modulation of Graves' orbital fibroblast proliferation by cytokines and glucocorticoid receptor agonists. Investigative Ophthalmology and Visual Science 35 120-127.

Heufelder AE, Bahn RS \& Smith TJ 1992 Regulation by glucocorticoids of interferon gamma-induced HLA-DR antigen expression in cultured human orbital fibroblasts. Clinical Endocrinology 37 59-63.

Kaback LA \& Smith TJ 1999 Expression of hyaluronan synthase messenger ribonucleic acids and their induction by interleukin-1\{beta $\}$ in human orbital fibroblasts: potential insight into the molecular pathogenesis of thyroid-associated ophthalmopathy. Journal of Clinical Endocrinology and Metabolism 84 4079-4084.

Kaminski HJ, Li Z, Richmonds C, Ruff RL \& Kusner L 2003 Susceptibility of ocular tissues to autoimmune diseases. Annals of the New York Academy of Sciences 998 362-374.

Kotelevtsev Y, Holmes MC, Burchell A, Houston PM, Schmoll D, Jamieson P, Best R, Brown R, Edwards CRW, Seckl JR et al. 1997 11ß-Hydroxysteroid dehydrogenase type 1 knockout mice show attenuated glucocorticoidinducible responses and resist hyperglycaemia on obesity and stress. PNAS 94 14924-14929.

Kumar S \& Bahn RS 2003 Relative overexpression of macrophage-derived cytokines in orbital adipose tissue from patients with Graves' ophthalmopathy. Journal of Clinical Endocrinology and Metabolism 88 4246-4250. 
Masuzaki H, Paterson J, Shinyama H, Morton NM, Mullins JJ, Seckl JR \& Flier JS 2001 A transgenic model of visceral obesity and the metabolic syndrome. Science 294 2166-2170.

Masuzaki H, Yamamoto H, Kenyon CJ, Elmquist JK, Morton NM, Paterson JM, Shinyama H, Sharp MGF, Fleming S, Mullins JJ et al. 2003 Transgenic amplification of glucocorticoid action in adipose tissue causes high blood pressure in mice. Journal of Clinical Investigation 112 83-90.

Montague CT, Prins JB, Sanders L, Digby JE \& O'Rahilly S 1997 Depot- and sex-specific differences in human leptin mRNA expression: implications for the control of regional fat distribution. Diabetes 46 342-347.

Muhlberg T, Joba W, Spitzweg C, Schworm H-D, Heberling H-J \& Heufelder AE 2000 Interleukin-1 receptor antagonist ribonucleic acid and protein expression by cultured Graves' and normal orbital fibroblasts is differentially modulated by dexamethasone and irradiation. Journal of Clinical Endocrinology and Metabolism 85 734-742.

Neels JG \& Olefsky JM 2006 Inflamed fat: what starts the fire? Journal of Clinical Investigation 116 33-35.

Niesler CU, Siddle K \& Prins JB 1998 Human preadipocytes display a depotspecific susceptibility to apoptosis. Diabetes 47 1365-1368.

Onyimba CU, Vijapurapu N, Curnow SJ, Khosla P, Stewart PM, Murray PI, Walker EA \& Rauz S 2006 Characterisation of the prereceptor regulation of glucocorticoids in the anterior segment of the rabbit eye. Journal of Endocrinology 190 483-493.

Petruschke T \& Hauner H 1993 Tumor necrosis factor-alpha prevents the differentiation of human adipocyte precursor cells and causes delipidation of newly developed fat cells. Journal of Clinical Endocrinology and Metabolism $\mathbf{7 6}$ 742-747.

Pietiläinen KH, Kannisto K, Korsheninnikova E, Rissanen A, Kaprio J, Ehrenborg E, Hamsten A \& Yki-Järvinen H 2006 Acquired obesity increases CD68 and TNF- $\alpha$ and decreases adiponectin gene expression in adipose tissue - a study in monozygotic twins. Journal of Clinical Endocrinology and Metabolism 91 2776-2781.

Prabhakar BS, Bahn RS \& Smith TJ 2003 Current perspective on the pathogenesis of Graves' disease and ophthalmopathy. Endocrine Reviews $\mathbf{2 4}$ 802-835.

Prins JB, Niesler CU, Winterford CM, Bright NA, Siddle K, O’Rahilly S, Walker NI \& Cameron DP 1997 Tumor necrosis factor-alpha induces apoptosis of human adipose cells. Diabetes 46 1939-1944.

Rauz S, Cheung CMG, Wood PJ, Coca-Prados M, Walker EA, Murray PI \& Stewart PM 2003 Inhibition of 11ß-hydroxysteroid dehydrogenase type 1 lowers intraocular pressure in patients with ocular hypertension. Quarterly Journal of Medicine 96 481-490.

Rootman J 2002 Pathophysiologic patterns of orbital disease. In Diseases of the Orbit: a Multidisciplinary Approach, 2nd edn, Ed. J Rootman. Philadelphia, PA: Lippincott Williams \& Wilkins.

Smith TJ 2004 Novel aspects of orbital fibroblast pathology. Journal of Endocrinological Investigation 27 246-253.

Smith TJ, Sempowski GD, Wang HS, Del Vecchio PJ, Lippe SD \& Phipps RP 1995 Evidence for cellular heterogeneity in primary cultures of human orbital fibroblasts. Journal of Clinical Endocrinology and Metabolism 80 2620-2625.

Smith TJ, Koumas L, Gagnon A, Bell A, Sempowski GD, Phipps RP \& Sorisky A 2002 Orbital fibroblast heterogeneity may determine the clinical presentation of thyroid-associated ophthalmopathy. Journal of Clinical Endocrinology and Metabolism 87385.
Stewart PM, Murry BA \& Mason JI 1994 Human kidney 11ß-hydroxysteroid dehydrogenase is a high affinity nicotinamide adenine dinucleotidedependent enzyme and differs from the cloned type I isoform. Journal of Clinical Endocrinology and Metabolism 79 480-484.

Thieringer R, Grande CBL, Carbin L, Cai T, Wong B, Wright SD \& Hermanowski-Vosatka A 2001 11ß-Hydroxysteroid dehydrogenase type 1 is induced in human monocytes upon differentiation to macrophages. Journal of Immunology 167 30-35.

Tomlinson JW, Bujalska I, Stewart PM \& Cooper MS 2000 The role of $11 \beta$ hydroxysteroid dehydrogenase in central obesity and osteoporosis. Endocrine Research 26 711-722.

Tomlinson JW, Moore J, Cooper MS, Bujalska I, Shahmanesh M, Burt C, Strain A, Hewison M \& Stewart PM 2001 Regulation of expression of $11 \beta$ hydroxysteroid dehydrogenase type 1 in adipose tissue: tissue specific induction by cytokines. Endocrinology 142 1982-1989.

Tomlinson JW, Sinha B, Bujalska I, Hewison M \& Stewart PM 2002 Expression of $11 \beta$-hydroxysteroid dehydrogenase type 1 in adipose tissue is not increased in human obesity. Journal of Clinical Endocrinology and Metabolism 87 5630-5635.

Tomlinson JW, Walker EA, Bujalska IJ, Draper N, Lavery GG, Cooper MS, Hewison M \& Stewart PM 2004 11ß-Hydroxysteroid dehydrogenase type 1: a tissue-specific regulator of glucocorticoid response. Endocrine Reviews 25 831-866.

Valyasevi RW, Jyonoucgi SC, Dutton CM, Munsakul N \& Bahn RS 2001 Effect of tumour necrosis factor- $\alpha$, interferon- $\gamma$, and expression of thyrotropin receptor in human orbital preadipocyte fibroblasts. Journal of Clinical Endocrinology and Metabolism 86 903-908.

Vikman HL, Hreniuk SP, Kauffman GF, LaNoue KF, Martin LF \& Ohisalo JJ 1995 Cyclic AMP and glycerol concentrations in freeze-clamped human omental and subcutaneous adipose tissues. International Journal of Obesity and Related Metabolic Disorders 19 388-391.

Weisberg SP, McCann DM, Desai M, Rosenbaum M, Leibel RL \& Ferrante AW 2003 Obesity is associated with macrophage accumulation in adipose tissue. Journal of Clinical Investigation 112 1796-1808.

Wellen KE \& Hotamisligil GS 2003 Obesity-induced inflammatory changes in adipose tissue. Journal of Clinical Investigation 112 1785-1788.

Wolfram-Gabel R \& Kahn JL 2002 Adipose body of the orbit. Clinical Anatomy 15 186-192.

Xu H, Barnes GT, Yang Q, Tan G, Yang D, Chou CJ, Sole J, Nichols A, Ross JS, Tartaglia LA et al. 2003 Chronic inflammation in fat plays a crucial role in the development of obesity-related insulin resistance. Journal of Clinical Investigation 112 1821-1830.

Zhang TY, Ding X \& Daynes RA 2005 The expression of $11 \beta$-hydroxysteroid dehydrogenase type I by lymphocytes provides a novel means for intracrine regulation of glucocorticoid activities. Journal of Immunology 174 879-889.

Received in final form 3 November 2006

Accepted 6 November 2006

Made available online as an Accepted Preprint 13 November 2006 